\title{
MAJA WOJCIECHOWSKA
}

Wydział Filologiczny Uniwersytetu Gdańskiego

\section{Rola zaufania w budowaniu kapitału społecznego w środowisku zawodowym bibliotekarzy. Wyniki badania}

\begin{abstract}
Streszczenie. W artykule podjęto zagadnienie „zaufania”, które uważane jest za warunek niezbędny do budowania kapitału społecznego. Kapitał społeczny oraz zaufanie odgrywają istotną rolę $\mathrm{w}$ działalności wielu instytucji i społeczności, także bibliotek. Wzmacniają relacje z otoczeniem, usprawniają współpracę z partnerami i współpracownikami, ograniczają lęk i konflikty, są również stymulantami rozwoju. W celu dokonania diagnozy tego zjawiska w środowisku bibliotek przeprowadzono badania, które objęły 20 krajów świata. Analiza zaprezentowana w artykule objęła zarówno ustalenie poziomu zaufania wśród grupy zawodowej bibliotekarzy, jak i skorelowanie z innymi czynnikami (zmienne niezależne, takie jak wiek, typ biblioteki, stanowisko itd.) oraz zmienne zależne. Ustalono, że bibliotekarze posiadają wysoki poziom zaufania do innych ludzi, natomiast respondenci, którzy zadeklarowali, że ufają innym, charakteryzują się również wyższym poziomem indywidualnego kapitału społecznego, mają większą sieć społeczna, bardziej angażują się w działania charytatywne i obywatelskie, są też bardziej nastawieni na życie rodzinne oraz kontakty przyjacielskie. Wydaje się, że takie postawy społeczne mogą być szczególnie pożądane na określonych stanowiskach bibliotecznych.
\end{abstract}

Słowa kluczowe: zaufanie, kapitał społeczny, sieci społeczne, biblioteki.

\section{Wstęp}

Najnowsze badania pokazuja, że sukces funkcjonowania instytucji bibliotecznych w lokalnych społecznościach nie opiera się wyłącznie na zapewnianiu przez nie dostępu do interesujących zbiorów, nowych technologii czy atrakcyjnych usług informacyjnych. Coraz częściej zwraca się uwagę, że istotną rolę odgrywają takie kwestie jak: tradycje, normy społeczne oraz wartości wzmacniane i pielęgnowane przez biblioteki, a także role społeczne, które odgrywaja, i wreszcie zaufanie, które budzą. Są to 
składniki stanowiące budulec kapitału społecznego, uznawane za głębsze pokłady struktury społecznej, niezbędne, aby biblioteka nie pełniła funkcji instytucji „zewnętrznej”, ,obcej”, lecz „wpisywała się" w lokalną strukturę społeczna, stanowiąc jej integralne ogniwo.

W zależności od przyjętej koncepcji działania mówi się o bibliotekach-hipermarketach, w których dominują anonimowość, brak silnych relacji z użytkownikami, płytkie i krótkie kontakty opierające się na niemal mechanicznych czynnościach i zachowaniach związanych z obsługa, oraz o bibliotekach nastawionych na pogłębiony i spersonalizowany kontakt z czytelnikiem, budowanie wspólnoty, zaufania, wzajemnej akceptacji i aktywizacji ${ }^{1}$. Oba modele działania są słuszne, ponieważ każdy z nich odpowiada na specyficzne i zarazem przeciwstawne potrzeby odbiorców - tych samodzielnych i niezależnych, pragnących neutralnej przestrzeni, w której sprawnie mogą zaspokoić swoje potrzeby informacyjne, jak i tych, którzy od biblioteki oczekują bliższych, spersonalizowanych działań, dążą do budowania silnych więzi, identyfikują się z nią i pragną budowania wspólnoty. Jednakże jedynie model "zaangażowany" będzie przyczyniał się do budowania kapitału społecznego, a więc będzie korzystniejszy z punktu widzenia kształtowania relacji społecznych. Niezależnie jednak od przyjętego modelu można mówić o zaufaniu jako o czynniku wzmacniającym funkcjonowanie biblioteki - w przypadku biblioteki-hipermarketu będzie to zaufanie związane ze stosowanymi standardami i jakością usług, w przypadku zaś biblioteki stanowiącej zinstytucjonalizowaną formę kapitału społecznego będzie to zaufanie odnoszące się do głębszych pokładów relacji w ramach określonej społeczności. $\mathrm{W}$ artykule zostanie szerzej przedstawione zagadnienie zaufania jako czynnika kształtującego charakter relacji pomiędzy bibliotekarzami a odbiorcami usług bibliotecznych - członków lokalnych społeczności.

\section{Pojęcie kapitału społecznego}

Z uwagi na liczne zmiany zachodzące we współczesnych społeczeństwach oraz próby ich tłumaczenia kapitał społeczny stał sięjedną z chętniej omawianych i analizowanych kategorii. Choć wzmianki o tym zjawisku pojawiały się już na początku XX wieku, to dopiero Robert Putnam -

1 M. Paul, Wptyw społeczny bibliotek publicznych. Na przykładach inicjatywy bibliotecznej „Wykietkuj na rynku pracy” oraz korzystania z mazowieckich bibliotek publicznych, Warszawa 2018, praca doktorska; M. Wojciechowska, Kształtowanie kapitału społecznego - ujęcie z perspektywy bibliotekoznawczej, Warszawa 2019, s. 198-208. 
amerykański politolog - ugruntował pozycję kapitału społecznego w nauce, prowadząc wieloletnie studia nad włoskim społeczeństwem² ${ }^{2}$ by następnie przenieść pewne wnioski na grunt społeczeństwa amerykańskiego $^{3}$. Putnam uważał, że kapitał społeczny to sieci, normy i zaufanie, a więc te elementy życia społecznego, które umożliwiają członkom społeczeństwa skuteczniejsze osiąganie celów. Cele te mogą być związane zarówno z dostępem do określonych zasobów fizycznych, jak i ze wsparciem emocjonalnym grupy, dostępem do wiedzy eksperckiej czy wspólną mobilizacją by zrealizować określone dążenie ważne dla jednostki lub całej społeczności.

Poza Putnamem do ważniejszych badaczy kapitału społecznego należy zaliczyć także Jamesa Colemana, Pierre'a-Félixa Bourdieu, Nana Lina, Alejandro Portesa oraz Francisa Fukuyamę. Ich koncepcje przenikały się i uzupełniały, lecz każdy z nich kapitał społeczny definiował odrębnie, wprowadzając nowe elementy i zwracając uwagę na różne aspekty tego zjawiska. Niezależnie jednak od uwypuklanych różnic w postrzeganiu i badaniu kapitału społecznego zawsze podkreślane były: potrzeba integracji społecznej, dążenie do wspólnotowości i przeciwstawianie się alienacji, która zaczyna stanowić poważny problem współczesnych społeczeństw.

Kapitał społeczny można określić jako zdolność jednostek do łączenia się w grupy i tworzenia sieci relacji, które są oparte na zaufaniu, wzajemnym wsparciu i integracji, co umożliwia realizację wspólnych interesów, zadań, projektów czy przedsięwzięć. Przy czym w szerszym aspekcie kapitał społeczny będzie dotyczył większych grup społecznych (społeczeństwa), w węższym zaś związany jest z funkcjonowaniem konkretnych organizacji, np. bibliotek. W ramach badań bibliologicznych kapitał społeczny rozpatrywany jest zarówno na poziomie grup społecznych (otoczenie biblioteki), jak również na poziomie organizacyjnym (biblioteka jako organizacja). Badane są możliwości, jakimi dysponują biblioteki w zakresie wspierania rozwoju kapitału społecznego swoich pracowników oraz społeczności lokalnych, jak również korzyści, które może przynieść rozwój kapitału społecznego ${ }^{4}$. Możliwe jest także badanie kapitału społecznego w ujęciu indywidualnym - wówczas analizie poddawana jest jednostka, np. użytkownik lub pracownik biblioteki. Interesujące

2 R.D. Putnam, R. Leonardi, R.Y. Nanetti, Making democracy work: civic traditions in modern Italy, Princeton 1993.

3 R. Putnam, Samotna gra w kręgle: upadek i odrodzenie wspólnot lokalnych w Stanach Zjednoczonych, Warszawa 2008.

4 M. Wojciechowska, J. Kamińska, B. Żołędowska-Król, B. Jaskowska, Leksykon zarzadzania i marketingu w bibliotekoznawstwie, Warszawa 2019, s. 94. 
badania na ten temat prowadzili m.in.: Andreas Vårheim ${ }^{5}$, Eva Cox ${ }^{6}$ czy Catherine A. Johnson ${ }^{7}$, natomiast w Polsce Jarosław Działek oraz Monika Murzyn-Kupisz ${ }^{8}$.

\section{Zaufanie - interpretacja pojęcia oraz rola $\mathrm{w}$ budowaniu kapitału społecznego}

Pomimo różnic występujących w definicjach kapitału społecznego licznie formułowanych przez wielu badaczy na całym świecie można zaobserwować położenie nacisku na kilka kluczowych kwestii, a mianowicie - kapitał społeczny budowany jest dzięki synergicznemu działaniu ludzi funkcjonujących w ramach konkretnej sieci społecznej, a jego rozwój uzależniony jest od wspólnie podzielanych wartości, norm, zaufania i relacji międzyludzkich. Wzajemne zaufanie oraz wspólne normy i wartości stanowią platformę efektywnej współpracy, która jest warunkiem rozwoju indywidualnego i grupowego. Wyniki badań realizowanych w różnych środowiskach potwierdzają tezę, że rozwój kapitału społecznego jest możliwy dzięki zaufaniu $\mathrm{w}$ sieciach relacji. Zracjonalizowane zaufanie uważane jest za niezbędny warunek tworzenia produktywnych więzi we wszystkich sferach życia: w grupach społecznych, grupach ekonomicznych, w kontaktach i kontraktach finansowych, bankowych i handlowych, układach międzynarodowych i społecznych'. Wydaje się, że zaufanie może mieć również kluczowe znaczenie w działalności bibliotek, które

5 A. Vårheim, S. Steinmo, E. Ide, Do libraries matter? Public libraries and the creation of social capital, "Journal of Documentation” 2008, nr 6, s. 877-892; A. Vårheim, Gracious space: library programming strategies towards immigrants as tools in the creation of social capital, "Library \& Information Science Research” 2011, nr 1, s. 12-18; idem, Public libraries: places creating social capital?, „Library Hi Tech” 2009, nr 3, s. 372-381.

6 E. Cox, A safe place to go. Libraries and social capital, https://www.sl.nsw.gov.au/ sites/default/files/safe_place.pdf [dostęp: 10.09.2020].

7 C.A. Johnson, Social capital and the search for information: examining the role of social capital in information seeking behavior in Mongolia, "Journal of the American Society for Information Science and Technology" 2007, nr 58, s. 883-894; idem, How do public libraries create social capital? An analysis of interactions between library staff and patrons, „Library and Information Science Research” 2012, nr 34, s. 52-62.

8 J. Działek, M. Murzyn-Kupisz, Rola bibliotek w budowaniu i wzmacnianiu zasobów kapitału społecznego w województwie małopolskim, "Zarządzanie Biblioteką" 2014, nr 1, s. 9-32.

9 Kapitat społeczny: interpretacje, impresje, operacjonalizacja, red. M. Klimowicz, W. Bokajło, Warszawa 2010, s. 9. 
poza świadczeniem standardowych usług często dążą do integracji społeczności lokalnej, by móc lepiej wpływać na jej rozwój kulturalny, informacyjny, naukowy i społeczny. W niniejszym artykule zostaną przedstawione wyniki badań zaufania w środowisku zawodowym bibliotekarzy.

Kwestię zaufania (rozważaną w ramach analiz nad kapitałem społecznym) bardzo dobrze obrazuje podstawowa definicja, którą możemy odnaleźć w Słowniku języka polskiego. Zgodnie z nią "zaufanie” to: '1. przekonanie, że jakiejś osobie lub instytucji można ufać; 2. przekonanie, że czyjeś słowa, informacje itp. są prawdziwe; 3 . przekonanie, że ktoś posiada jakieś umiejętności i potrafi je odpowiednio wykorzystać'. $\mathrm{Z}$ kolei „zaufać” to: '1. powierzyć swoje sprawy osobie lub instytucji, której się ufa; 2. uznać, że czyjeś słowa, informacje itp. są prawdziwe; 3. uznać, że ktoś posiada jakieś umiejętności i potrafi je odpowiednio wykorzystać ${ }^{\prime 10}$.

Zatem zaufanie w kontekście działalności bibliotecznej dotyczy zarówno wiarygodności całej instytucji, jak i zachowań poszczególnych jej pracowników. Również odpowiedzialne i zaangażowane postawy użytkowników i całej społeczności lokalnej mogą wpływać na zwiększenie zaufania ze strony bibliotekarzy i w konsekwencji prowadzić do zacieśniania współpracy z biblioteką.

Biblioteki jako instytucje mogą cieszyć się wysokim poziomem zaufania, kiedy ich misja oraz podejmowane na bieżąco zadania są zgodne $z$ oczekiwaniami obsługiwanej społeczności i nie stoją w sprzeczności z powszechnie przyjętymi standardami oraz zasadami etyki. Chodzi tu zarówno o kwestie kluczowe i elementarne zarazem (często ujęte w statutach i regulaminach), takie jak równe traktowanie bez względu na status społeczny, sytuację życiową, wyznanie, przynależność etniczna, wiek, płeć itp., jak i o bieżące działania, zmierzające do integrowania lokalnych społeczności, rozwijania ich zainteresowań, talentów czy udzielania pomocy w sprawach utrudniających codzienne funkcjonowanie. Jako przykład tych ostatnich można wymienić pomoc seniorom w zakresie obsługi przez nich nowych technologii, udostępnianie przestrzeni bibliotecznych w celu przeprowadzania zebrań mieszkańców, współpracę w zakresie realizacji różnego rodzaju akcji charytatywnych itp. Całokształt działań biblioteki będzie wpływał na powiększanie lub utratę zaufania. Warto nadmienić, że biblioteki jako instytucje publiczne cieszą się obecnie na świecie jednym z najwyższych wskaźników zaufania. W Polsce odnotowujemy szczególnie niski poziom zaufania do przedstawicieli władzy centralnej, jednostek samorządu terytorialnego oraz organów publicznych: Sejmu,

${ }^{10}$ Stownik języka polskiego, https://sjp.pwn.pl [dostęp: 10.06.2020]. 
Senatu, sądów, Zakładu Ubezpieczeń Społecznych, a nawet Narodowego Funduszu Zdrowia ${ }^{11}$. Tymczasem w wielu sytuacjach biblioteki są jedynymi placówkami publicznymi, z którymi chcą współpracować osoby wykluczone społecznie. W tym kontekście w literaturze światowej bardzo często opisywany jest przykład środowisk imigranckich, którym biblioteki pozwalają przezwyciężyć bariery kulturowe i językowe, dają poczucie nadziei, godności i przynależności ${ }^{12}$.

W kontekście zaufania niezwykle istotna jest osoba samego bibliotekarza, ważne są: jego postawa, wiedza, cechy osobowościowe, zaangażowanie. To bowiem $\mathrm{w}$ dużej mierze od pracownika biblioteki zależy, czy zostaną zbudowane pozytywne relacje z użytkownikami lub nawet głębsza więź skutkująca zaufaniem. Odnosząc się do wcześniej zacytowanej definicji - to bibliotekarz kreuje przekonanie, że jego słowa i informacje są prawdziwe, że posiada umiejętności i potrafi ich użyć z korzyścią dla czytelnika.

Niektórzy autorzy reprezentują pogląd, że na istotę zaufania w kapitale społecznym składają się: prawda, dobro i pożyteczność. Prawda rozumiana jest tu jako zgodność uzewnętrznianego osądu wartościującego określony składnik rzeczywistości, przy czym osąd odkrywa fakty i prawidłowości tej rzeczywistości. Dobro stanowi kategorię moralną pozostającą w konotacji z wartościami ważnymi dla jednostki i społeczeństwa. Z kolei pożyteczność, czyli utylitaryzm, zasadza się na założeniu, że najwyższym moralnym celem działalności człowieka jest bycie pożytecznym i odrzucić należy te potrzeby, które są społecznie dysfunkcjonalne, a więc ograniczają, hamuja, a nawet dezintegrują życie społeczne ${ }^{13}$.

W książce Zaufanie. Fundament społeczeństwa Piotr Sztompka pisze:

W przeciwieństwie do wcześniejszych podejść psychologicznych, które traktowały zaufanie jako postawę jednostki, obecnie uznaje się je najczęściej za cechę relacji międzyludzkich, atrybut pola społeczno-jednostkowego, w którym funkcjonują ludzie, za kulturowy zasób wykorzystywany przez jednostki w działaniach ${ }^{14}$.

${ }^{11}$ M. Feliksiak (oprac.), Oceny działalności instytucji publicznych, 2018, nr 40, https:// www.cbos.pl/SPISKOM.POL/2018/K_040_18.PDF [dostęp: 10.11.2018].

${ }^{12}$ American Library Association, Guidelines for outreach to immigrant populations, https://tinyurl.com/3tf6233a [dostęp: 12.12.2019].

${ }^{13}$ A. Szałkowski, Składniki kapitału społecznego, "Zeszyty Naukowe Uniwersytetu Ekonomicznego w Krakowie" 2007, nr 755, s. 7-20.

${ }^{14}$ P. Sztompka, Zaufanie. Fundament społeczeństwa, Kraków 2007, s. 49. 
Jest ono zatem nie tylko fundamentem, na którym może być budowany kapitał społeczny, ale stanowi również podstawowy komponent życia społecznego zapewniający jego ciągłość i względną harmonię oraz czynnik wspierający rozwój kapitału kulturowego. Zaufanie to element niezbędny do współpracy ze środowiskiem zewnętrznym biblioteki (z partnerami, klientami), ale też do tworzenia satysfakcjonującego miejsca pracy, w którym bibliotekarze działający w zespołach (filiach, wydziałach, zespołach zadaniowych) budują kulturę zaufania i pozytywny klimat pracy. Pomimo istoty tego zjawiska jest ono dość rzadko poddawane badaniom i analizie. W literaturze polskiej temat ten w kontekście działalności bibliotek podjęła Małgorzata Kisilowska w artykule Czy lubicie się Państwo zakładać? O zaufaniu w bibliotece ${ }^{15}$.

\section{Cel, metodyka oraz ograniczenia przeprowadzonego badania}

W celu dokonania analizy zachowań społecznych w grupie zawodowej bibliotekarzy w 2018 roku rozpoczęto badanie kapitału społecznego w środowisku bibliotek. Pierwszy etap badania został zrealizowany wśród pracowników bibliotek różnych typów z 20 krajów świata. Drogą ankiety elektronicznej skierowano pytania do bibliotekarzy zatrudnionych w Australii, Austrii, Belgii, na Białorusi, w Czechach, Danii, we Francji, w Irlandii, Kanadzie, Niemczech, Nowej Zelandii, Polsce, Rosji, Słowacji, Stanach Zjednoczonych, Szwajcarii, Szwecji, Ukrainie, na Węgrzech oraz w Wielkiej Brytanii. Uzyskano ogółem 6593 ważne odpowiedzi, udzielone przez respondentów w 2018 i 2019 roku.

Prezentowana analiza stanowi część badania dotyczącego indywidualnego kapitału społecznego (IKS) bibliotekarzy, którego zakończenie planowane jest na 2022 rok. Celem wykonanej analizy było ustalenie, którzy respondenci mają najwyższy poziom zaufania do innych ludzi oraz które czynniki mogą mieć na nie wpływ. Uwzględniono takie zmienne niezależne, jak np.:

- kraj zatrudnienia,

- płeć,

- wiek,

- typ biblioteki,

${ }^{15}$ M. Kisilowska, Czy lubicie się Państwo zakładać? O zaufaniu w bibliotece, w: Biblioteka jako trzecie miejsce. Międzynarodowa Konferencja Biblioteki Uniwersytetu Łódzkiego, red. M. Wrocławska, J. Jerzyk-Wojtecka, Łódź 2011, s. 7-17. 
- stanowisko w bibliotece,

- wielkość miejscowości, w której pracuje respondent.

Próbowano również uzyskać informacje, czy bibliotekarzom, którzy deklarują zaufanie do innych ludzi, można przypisać jakieś charakterystyczne cechy bądź postawy:

- czy mają oni wyższy poziom indywidualnego kapitału społecznego?

- czy mają większą liczbę znajomych niż osoby, które nie deklarują zaufania, tj. czy bardziej rozbudowana sieć społeczna oraz liczne kontakty społeczne sprzyjają zwiększeniu zaufania do innych?

- czy częściej podejmują aktywność wolontariacka/społeczna, pomagają innym?

- czy częściej reprezentują postawy obywatelskie?

- czy mają inne cele życiowe niż pozostali respondenci (są bardziej nastawieni na życie rodzinne, towarzyskie, pomoc drugiemu człowiekowi)?

Za podstawę badania posłużyła deklaracja: „większości ludzi można ufać", która stosowana jest w badaniach kapitału społecznego, a do której ustosunkowywali się respondenci. W opracowaniu wyników do weryfikacji istotności zależności między odpowiedziami w skali nominalnej i w deklaracji, że "można ufać większości ludzi” zastosowano test chi-kwadrat niezależności. Do oceny różnic w częstości podejmowanych czynności między dwoma grupami pracowników (deklarujących, że można lub nie można ufać większości ludzi) zastosowano test różnic U Manna-Whitneya. Wszystkie testy zostały obliczone na poziomie istotności statystycznej alfa $=0,05$.

Ponieważ wykonana analiza została oparta na deklaracji, którą składali bibliotekarze, konieczne wydaje się przeprowadzanie w przyszłości badania uzupełniającego, które bazowałoby na odpowiedziach udzielonych przez użytkowników bibliotek oraz osoby niekorzystające z usług tych instytucji. Badanie takie pokazałoby poziom zaufania otoczenia do biblioteki.

\section{Wyniki badania zaufania w grupie zawodowej bibliotekarzy}

Analiza danych uzyskanych w badaniu pozwoliła na potwierdzenie niektórych zależności i zjawisk. Wyniki zostały zgrupowane w następujących blokach: 
1. Zaufanie do ludzi w zależności od zmiennych socjodemograficznych badanych pracowników bibliotek (tab. 1).

2. Zaufanie do innych ludzi a aktywność społeczna bibliotekarzy (tab. 2).

3. Zaufanie do innych ludzi a cele życiowe bibliotekarzy (tab. 3).

4. Zaufanie do innych ludzi a poziom indywidualnego kapitału społecznego bibliotekarzy (tab. 4).

5. Wielkość osobistej sieci społecznej bibliotekarzy a zaufanie do innych ludzi (tab. 5).

6. Zaufanie do innych ludzi a aktywność obywatelska bibliotekarzy (tab. 6, wykres 1).

W pierwszej kolejności próbowano ustalić, czy wybrane zmienne niezależne (jak wiek, płeć, typ biblioteki, stanowisko itp.) korelują w jakiś sposób z poziomem zaufania respondentów. Dane zbiorcze przedstawiono $\mathrm{w}$ tabeli 1.

Pierwszą zmienną poddaną analizie było państwo, w którym pracuje respondent. Jak pokazują wyniki badań światowych, poziom zaufania wśród ludzi może znacznie się różnić w zależności od kraju ich zamieszkania. Najwyższy poziom zaufania do drugiego człowieka w krajach Unii Europejskiej odnotowywany jest zwykle w Skandynawii, natomiast najniższy na Łotwie, w Portugalii i Polsce ${ }^{16}$. W przypadku Polski wpływ na postawy obywateli mogła mieć trudna historia kraju (zabory, wojny, opresyjny system komunistyczny sprzyjający konfidencji), a także wzrastająca alienacja społeczna jednostek i coraz mniej rodzinny styl życia. Nie bez znaczenia pozostaje również aktualna sytuacja polityczno-społeczna. Jak pokazały badania przeprowadzone przez autorkę, bibliotekarze z Polski charakteryzują się wyższym poziomem zaufania do drugiego człowieka niż reszta społeczeństwa. W badaniach z 1995 roku indeks poziomu zaufania Polaków wynosił 17,9 (przy średniej OECD 43) ${ }^{17}$, natomiast w 2008 roku deklarację: „większości ludzi można ufać” potwierdziło zaledwie 19\% Polaków ${ }^{18}$. W badaniu bibliotekarzy poziom deklarowanego zaufania dla Polski wyniósł 52,3\%. W przypadku innych krajów istotnie statystycznie najwyższy poziom zaufania osiągają bibliotekarze pracujący w Danii (96,0\%), Nowej Zelandii (84,6\%) i Australii (81,5\%), którzy zadeklarowali, że większości ludzi można ufać. Najniższy poziom uzyskały z kolei Słowacja (42,4\%), Białoruś (43,5\%) i Rosja (44,9\%) (wykres 1).

${ }^{16}$ Raport o Kapitale Intelektualnym Polski, Warszawa 2008, https://zds.kprm.gov.pl/ przegladaj-raport-o-kapitale-intelektualnym [dostęp: 27.10.2018].

17 Kapitał społeczny..., s. 212.

${ }^{18}$ Raport o Kapitale Intelektualnym... 


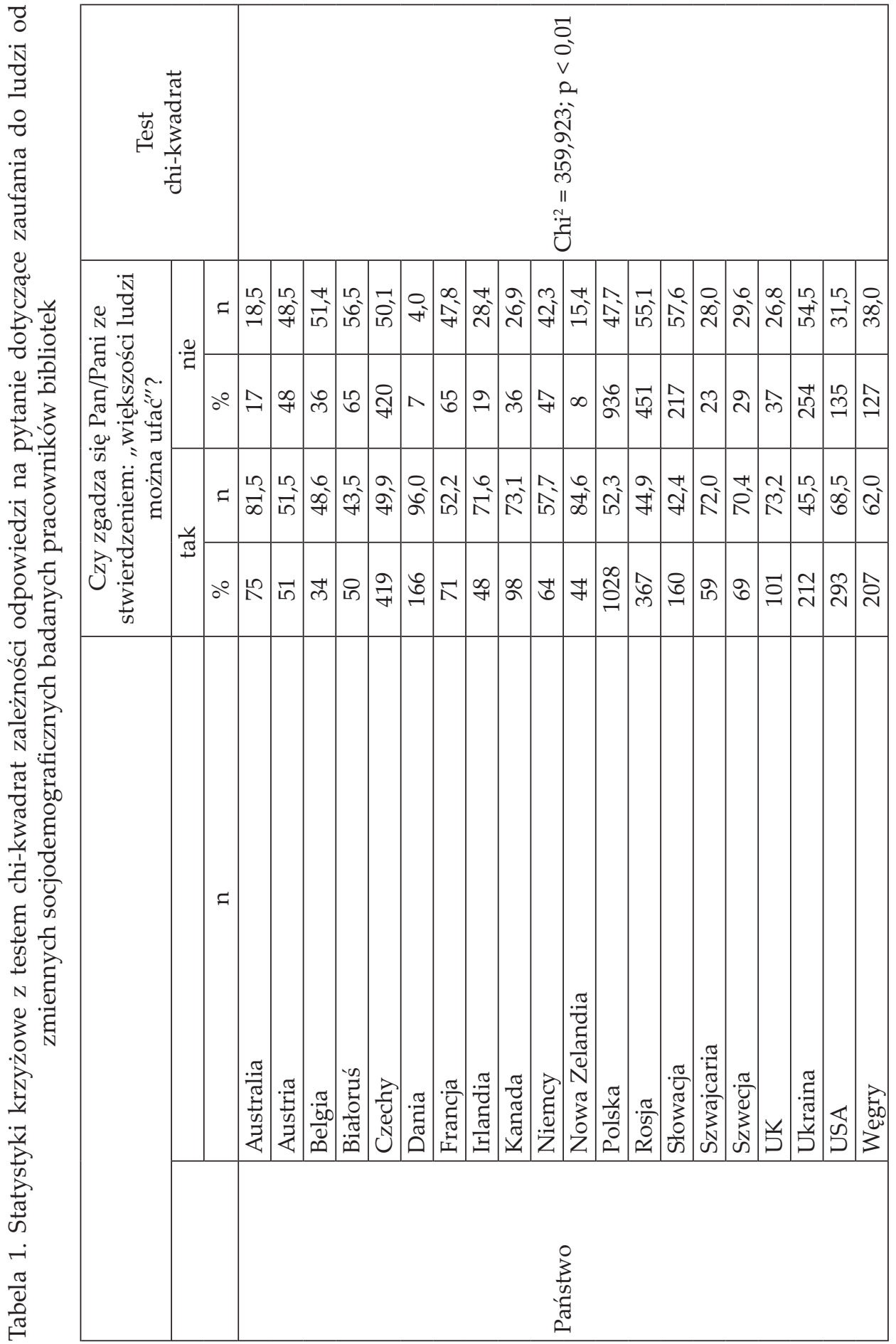




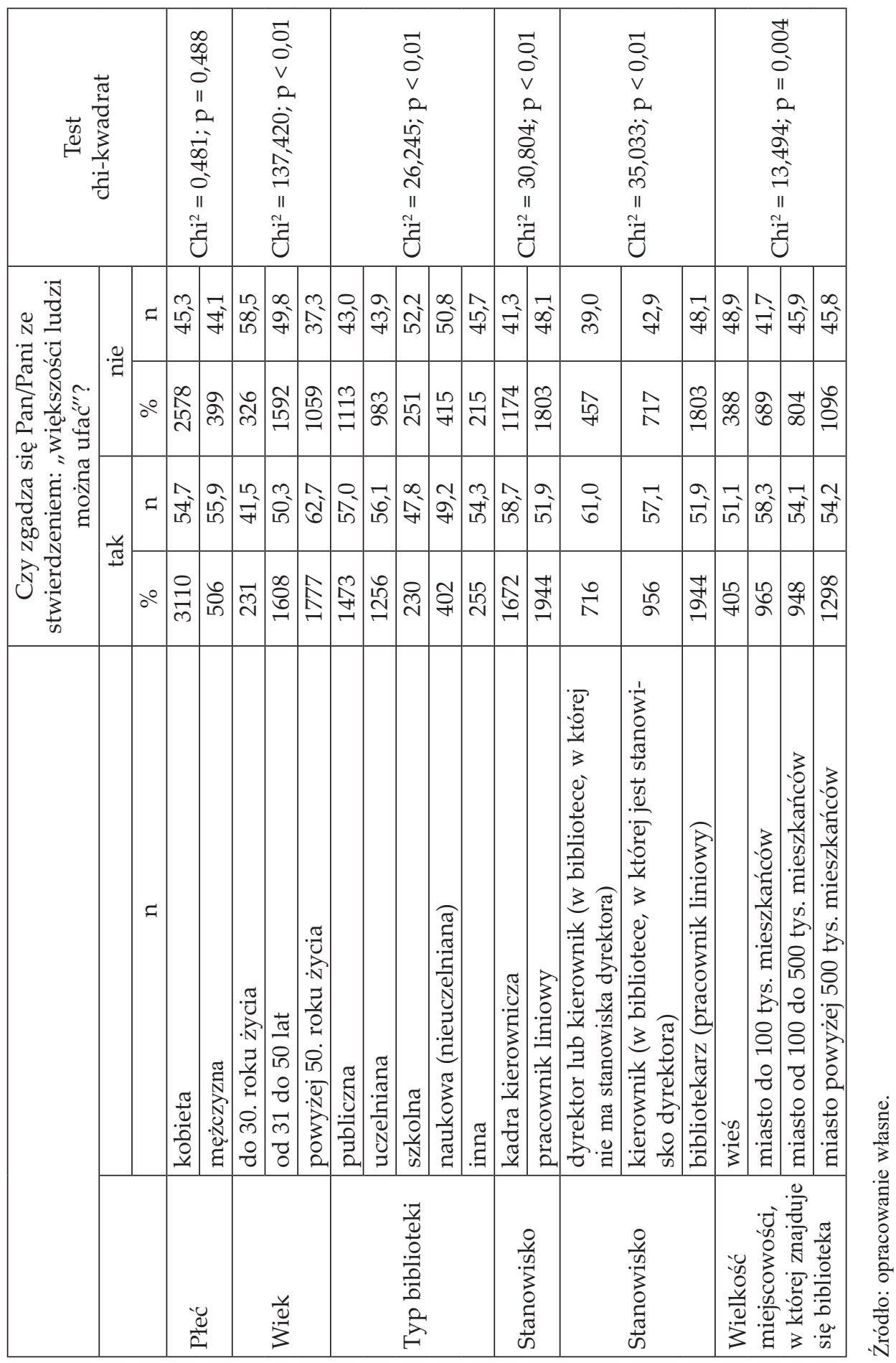




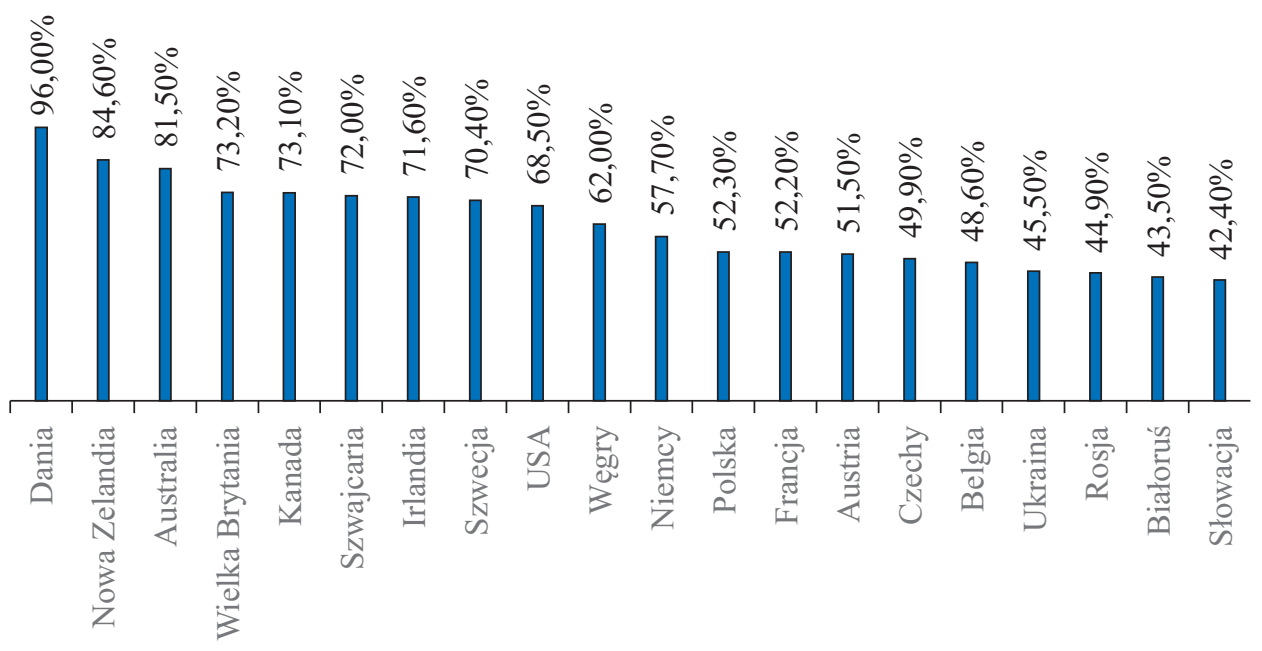

Wykres 1. Poziom zaufania bibliotekarzy do drugiego człowieka według kraju zatrudnienia

Źródło: opracowanie własne.

Poza krajem, w którym zatrudniony jest bibliotekarz, uwagę zwrócono także na wielkość miejscowości, w której zlokalizowana jest zatrudniająca go biblioteka. Wielkość aglomeracji budzi zainteresowanie badaczy kapitału społecznego, ponieważ do pewnego stopnia warunkuje ona charakter kontaktów społecznych. O ile ludzie zamieszkujący duże miasta częściej mają rozbudowane sieci znajomych oraz łatwiej jest im utrzymać stosunki towarzyskie, o tyle w małych miastach i we wsiach życie społeczne w większym stopniu koncentruje się na więziach rodzinnych. Inaczej rzecz ujmując - relacji jest mniej, ale mają one pogłębiony charakter. W miastach, pomimo wielu możliwości różnorodnego spędzania wolnego czasu, panuje większa anonimowość, a ludzie częściej postrzegani są przez pryzmat funkcji, które pełnią w społeczeństwie (lekarz, prawnik, tłumacz, bibliotekarz). Mimo to najniższym kapitałem społecznym odznaczają się osoby zamieszkujące wsie. $W$ badaniach przeprowadzonych wśród bibliotekarzy ludziom ufają najczęściej pracownicy z bibliotek zlokalizowanych w miastach do 100 tys. mieszkańców (58,3\%) (zob. wykres 2). Być może aglomeracje te zdołały połączyć atrybuty wsi (silniejsze więzi rodzinne) $\mathrm{z}$ atrybutami większych miast (silniejsze więzi przyjacielskie). Praca w niewielkim mieście może powodować wrażenie, że „zna się wszystkich" i dzięki temu nikt nie jest zupełnie obcy, co zwiększa zaufanie. Można przypuszczać, że w bibliotekach ulokowanych w małych miastach mniejsza jest anonimowość, bibliotekarze znają swoich czytelników, ale równocześnie są względem nich bardziej tolerancyjni, 


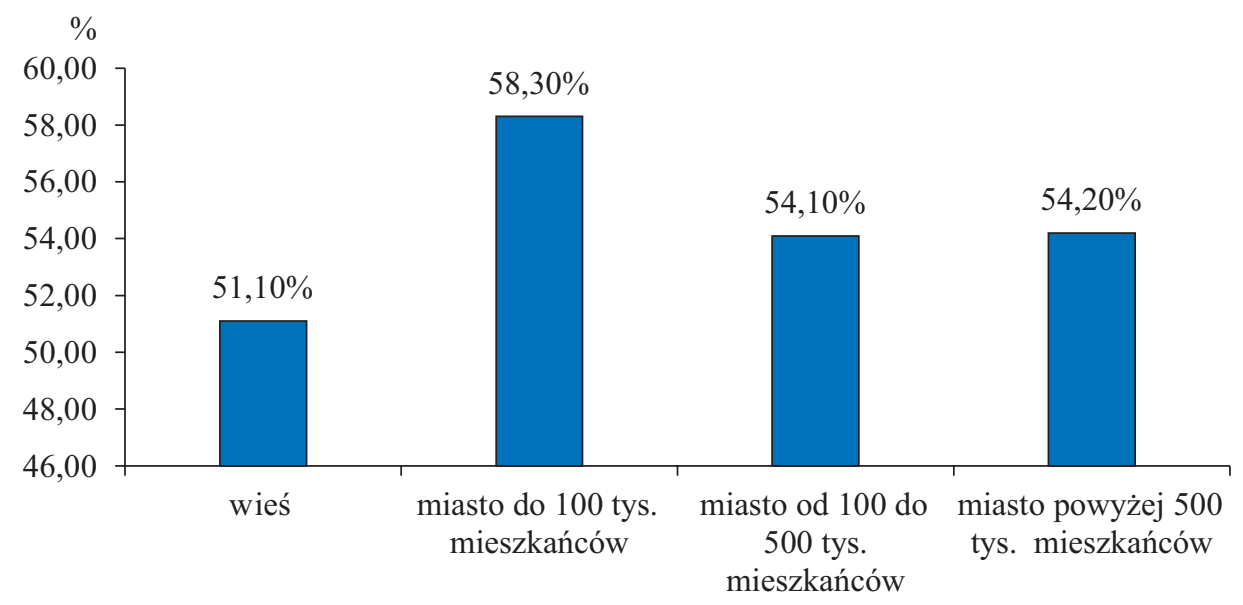

Wykres 2. Poziom zaufania bibliotekarzy do drugiego człowieka według wielkości miejscowości, w której znajduje się biblioteka

Źródło: opracowanie własne.

co generuje zaufanie. Jest to jednak tylko hipoteza, która powinna zostać zweryfikowana w dalszych badaniach.

Kolejną istotną zmienną uwzględnioną $\mathrm{w}$ badaniu był wiek respondentów. W tym przypadku wyniki uzyskane w grupie zawodowej bibliotekarzy są zbieżne z wynikami w innych grupach. Badacze kapitału społecznego w swoich analizach wskazuja, że to respondenci młodzi, częściej niż ankietowani w średnim i późniejszym wieku, deklarują nieufność do innych. Co prawda osoby starsze utrzymują mniej kontaktów społecznych, jednak wyrażają one zaufanie do ludzi, rzadziej reprezentują postawę nieufności, określaną w badaniach zwrotem: „ostrożności nigdy za wiele"19. W przypadku bibliotekarzy wraz z wiekiem częściej pojawiają się deklaracje o zaufaniu do drugiego człowieka; takie zaufanie pracownicy młodzi do 30. roku życia deklarują w 41,5\%, w wieku 31-50 lat - w 50,3\% i w wieku powyżej 50 lat - w 62,7\% (zob. wykres 3).

Nieco większe zaufanie do innych deklarują mężczyźni (55,9\%) niż kobiety $(54,7 \%)$, choć $\mathrm{w}$ tym wypadku jest to niewielka różnica wynosząca zaledwie 1,2\%. Niektórzy badacze zjawisko to (obecne także $\mathrm{w}$ innych grupach zawodowych) tłumaczą sytuacją społeczną kobiet, które $\mathrm{w}$ większym stopniu zaangażowane są $\mathrm{w}$ relacje $\mathrm{z}$ najbliższymi, częściej sprawują opiekę nad dziećmi i osobami starszymi, rzadziej zaś

${ }^{19}$ Zob. np. D. Bazuń, M. Kwiatkowski, Lubuskie sieci inkluzji: tożsamość regionalna, kapitał społeczny, aktywna integracja, Warszawa 2015; K. Growiec, Kapitał społeczny. Geneza i społeczne konsekwencje, Warszawa 2011, s. 73-77. 


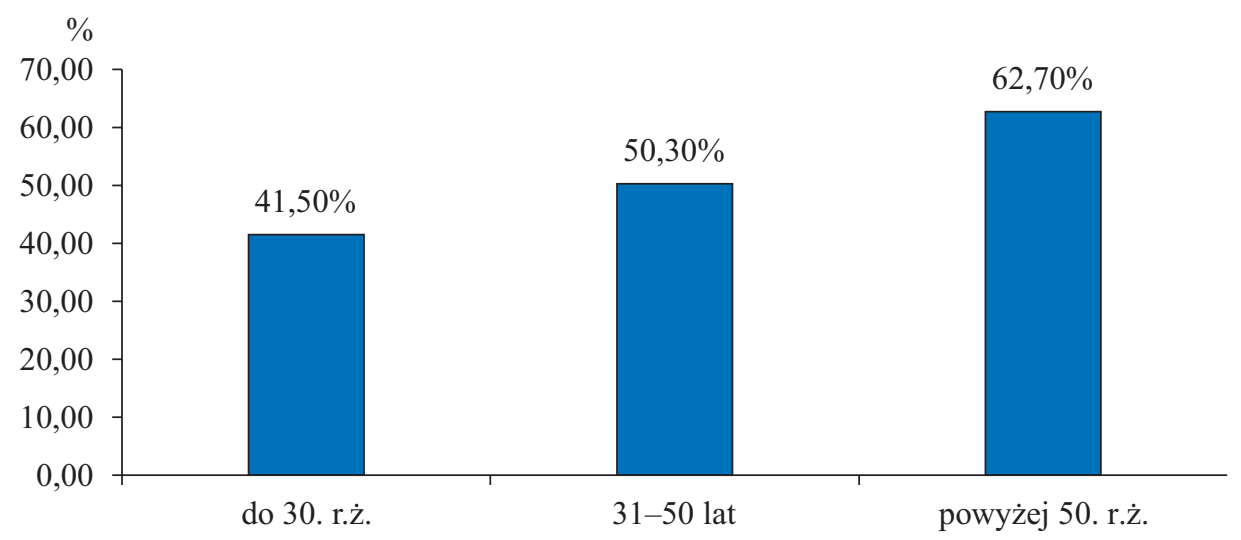

Wykres 3. Poziom zaufania bibliotekarzy do drugiego człowieka według wieku Źródło: opracowanie własne.

pielęgnują sferę koleżeńską przez co ich sieć kontaktów społecznych zanika, zmienia się pozycja w strukturze społecznej, a zaufanie do obcych ogranicza ${ }^{20}$. Niektóre badania pokazuja że sieć społeczna kobiet jest średnio o 0,73 znajomego mniejsza niż sieć mężczyzn ${ }^{21}$. Również kapitał społeczny kobiet przybiera odmienną formę niż kapitał mężczyzn - w większym stopniu angażują się one we wsparcie emocjonalne. Dla mężczyzn pomoc oznacza częściej wsparcie materialne, finansowe oraz organizacyjne.

Największe zaufanie do innych ludzi można odnotować wśród bibliotekarzy zatrudnionych $\mathrm{w}$ bibliotekach publicznych $(57,0 \%)$ (zob. wykres 4). Być może wynika ono z częstych kontaktów ze znacznie zróżnicowanymi odbiorcami usług, koniecznością otwartości na potrzeby drugiego człowieka oraz zatrudnianiem w tych właśnie instytucjach pracowników z określonymi predyspozycjami społecznymi, które ułatwiają integrację z lokalną społecznością oraz pomagają w animacji czytelniczej i kulturalnej. Zaufanie ze strony bibliotekarzy bibliotek publicznych może być również pogłębiane w przypadku pozytywnych interakcji z użytkownikami oraz gdy lokalna społeczność wykazuje chęć współpracy, jest aktywna i cechuje się pozytywnymi zachowaniami, co powoduje sprzężenie zwrotne ze strony personelu biblioteki. W tym kontekście interesujące byłyby badania pokazujące poziom zaufania wśród bibliotekarzy pracujących $\mathrm{w}$ tzw. trudnych dzielnicach, zagrożonych przemocą i agresją.

\footnotetext{
${ }^{20}$ K. Growiec, op. cit., s. 76.

${ }^{21}$ Ibidem, s. 119.
} 


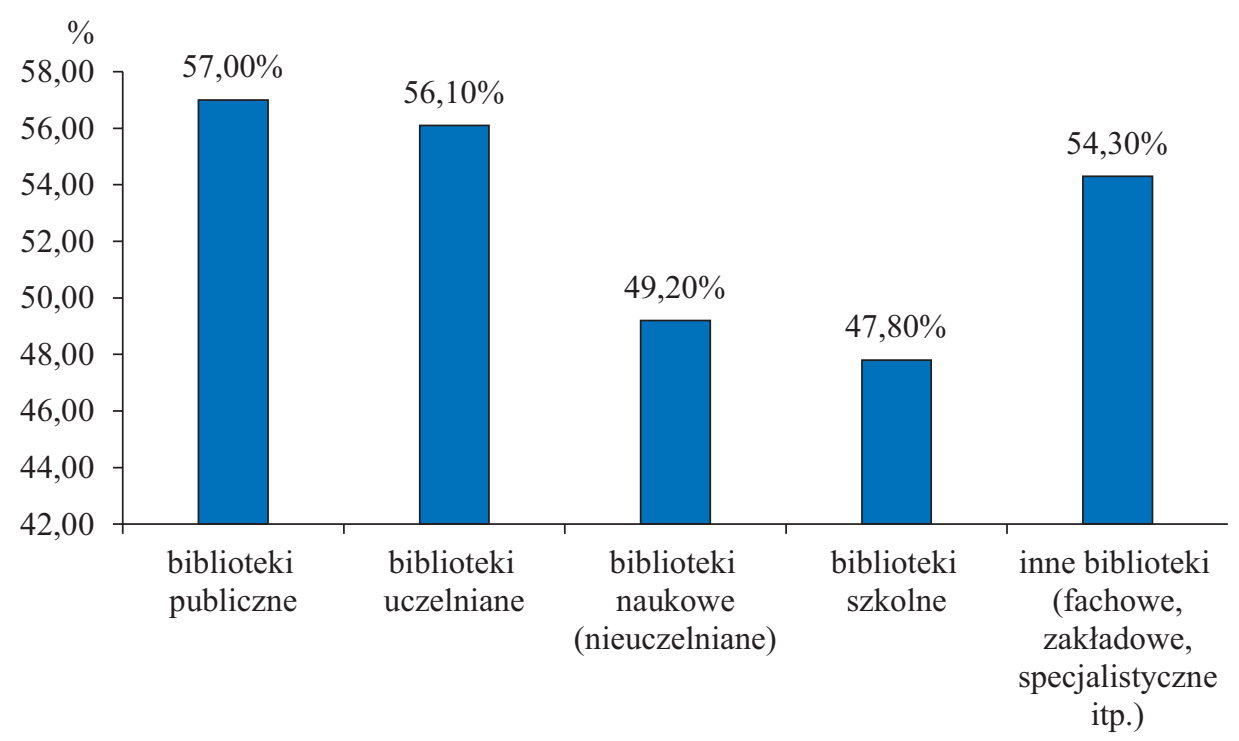

Wykres 4. Poziom zaufania bibliotekarzy do drugiego człowieka według typu biblioteki

Źródło: opracowanie własne.

Ostatnią analizowaną zmienną niezależną jest stanowisko, na którym byli zatrudnieni respondenci. W badaniach społecznych dominuje teza, że osoby na wyższych stanowiskach (kadra kierownicza) powinny charakteryzować się wysokim poziomem indywidualnego kapitału społecznego oraz posiadać aktywną sieć społeczna, która może zapewnić im $\mathrm{w}$ razie potrzeby wsparcie, dostęp do określonych zasobów i wiedzy. W wypadku kadry kierowniczej bibliotek istotnie można zaobserwować wyższy poziom kapitału społecznego - dyrektorzy w badaniu uzyskali wynik 67,42 IKS, podczas gdy personel liniowy 66,34 IKS ${ }^{22}$. Czy podobnie jest z zaufaniem do drugiego człowieka? Jest to ważna kwestia, ponieważ zaufanie w wypadku kadry kierowniczej i dyrektorów bibliotek może wpływać na łatwiejsze zawiązywanie współpracy z partnerami, lepsze kontakty z zespołem pracowniczym oraz większą otwartość na współpracę ze społecznością lokalną. Zaufanie może być czynnikiem wzmacniającym pozytywne relacje $\mathrm{z}$ użytkownikami biblioteki, ograniczać potrzebę stosowania zakazów, nakazów i regulaminów oraz prowadzić do wiary $\mathrm{w}$ racjonalne i odpowiedzialne zachowania czytelników. Jak pokazało

${ }^{22}$ M. Wojciechowska, Indywidualny kapitał społeczny i aktywność społeczna kadry kierowniczej bibliotek. Przegląd wyników badań z dwudziestu krajów świata, „Przegląd Biblioteczny" 2020, z. 4, s. 445-460. 
badanie, podobnie jak w przypadku indywidualnego kapitału społecznego, najwyższym poziomem zaufania do innych ludzi charakteryzują się dyrektorzy (61\%) i kierownicy bibliotek (57,1\%) (wykres 5).

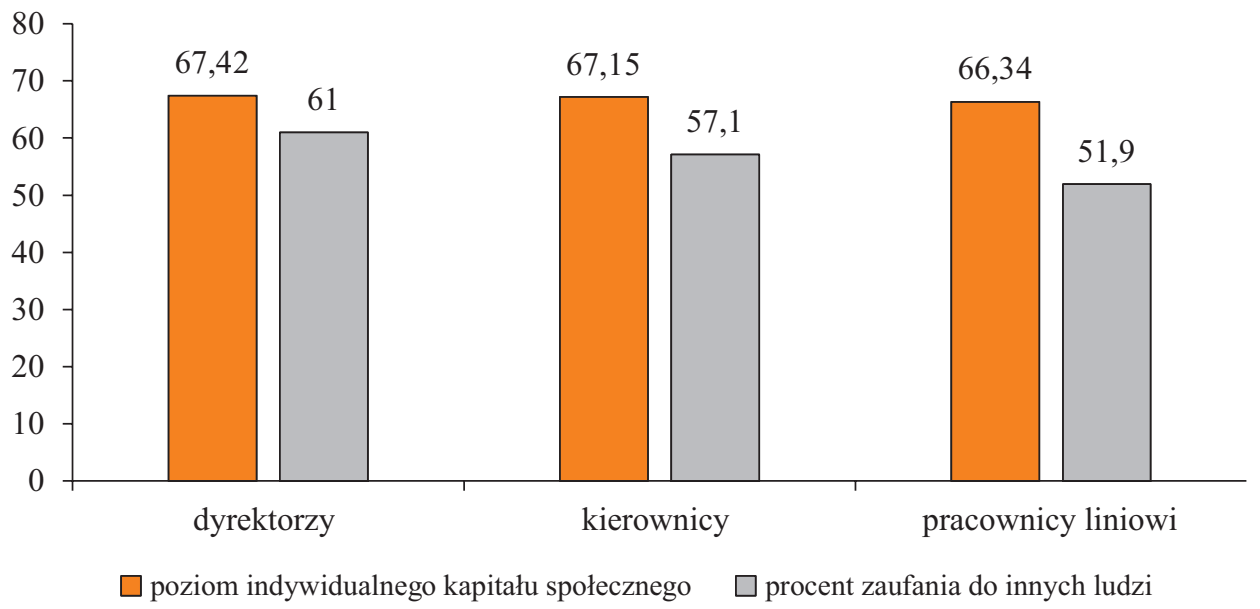

Wykres 5. Poziom zaufania oraz indywidualnego kapitału społecznego wśród kadry bibliotek z podziałem na stanowiska kierownicze i niekierownicze Źródło: opracowanie własne.

Tabela 2. Zaufanie do innych ludzi a aktywność społeczna bibliotekarzy

\begin{tabular}{|c|c|c|c|c|c|c|c|}
\hline & \multicolumn{4}{|c|}{$\begin{array}{c}\text { Czy zgadza się Pan/Pani ze stwier- } \\
\text { dzeniem: „większości ludzi moż- } \\
\text { na ufać”? }\end{array}$} & \multirow{2}{*}{\multicolumn{2}{|c|}{ Test chi-kwadrat }} \\
\hline & & \multicolumn{2}{|c|}{ tak } & \multicolumn{2}{|c|}{ nie } & & \\
\hline & & $\mathrm{n}$ & $\%$ & $\mathrm{n}$ & $\%$ & $\mathrm{Ch}^{2}$ & $\begin{array}{l}\text { istot- } \\
\text { ność }\end{array}$ \\
\hline \multirow[b]{2}{*}{$\begin{array}{l}\text { Czy kiedykolwiek } \\
\text { zdarzyło się Panu/ } \\
\text { Pani dobrowol- } \\
\text { nie i nieodpłatnie } \\
\text { pracować na rzecz } \\
\text { swojego środo- } \\
\text { wiska, Kościoła, } \\
\text { osiedla, wsi, miasta } \\
\text { albo też praco- } \\
\text { wać społecznie na } \\
\text { rzecz potrzebują- } \\
\text { cych? }\end{array}$} & tak & 3028 & 83,74 & 2301 & 77,29 & & \\
\hline & nie & 588 & 16,26 & 676 & 22,71 & 43,785 & $p<0,01$ \\
\hline
\end{tabular}


cd. tabeli 2

\begin{tabular}{|c|c|c|c|c|c|c|c|}
\hline & \multicolumn{4}{|c|}{$\begin{array}{c}\text { Czy zgadza się Pan/Pani ze stwier- } \\
\text { dzeniem: „większości ludzi moż- } \\
\text { na ufać”? }\end{array}$} & \multirow{2}{*}{\multicolumn{2}{|c|}{ Test chi-kwadrat }} \\
\hline & & \multicolumn{2}{|c|}{ tak } & \multicolumn{2}{|c|}{ nie } & & \\
\hline & & $\mathrm{n}$ & $\%$ & $\mathrm{n}$ & $\%$ & $\mathrm{Ch}^{2}$ & $\begin{array}{l}\text { istot- } \\
\text { ność }\end{array}$ \\
\hline \multirow{2}{*}{$\begin{array}{l}\text { Czy w ciagu ostat- } \\
\text { nich pięciu lat } \\
\text { pracował/a Pan/ } \\
\text { Pani jako wolonta- } \\
\text { riuszka? }\end{array}$} & tak & 1853 & 51,26 & 1216 & 40,85 & & \\
\hline & nie & 1762 & 48,74 & 1761 & 59,15 & 71,364 & $p<0,01$ \\
\hline
\end{tabular}

Źródło: opracowanie własne.

Tabela 3. Zaufanie do innych ludzi a cele życiowe bibliotekarzy

\begin{tabular}{|c|c|c|c|c|c|c|c|}
\hline & \multicolumn{4}{|c|}{$\begin{array}{l}\text { Czy zgadza się Pan/Pani ze } \\
\text { stwierdzeniem: „większości } \\
\text { ludzi można ufać”? }\end{array}$} & \multirow{2}{*}{\multicolumn{2}{|c|}{ Test chi-kwadrat }} \\
\hline & & \multicolumn{2}{|c|}{ tak } & \multicolumn{2}{|c|}{ nie } & & \\
\hline & & $\mathrm{n}$ & $\%$ & $\mathrm{n}$ & $\%$ & $\mathrm{Ch}^{2}$ & istotność \\
\hline \multirow{8}{*}{$\begin{array}{l}\text { Proszę po- } \\
\text { dać, co jest } \\
\text { dla Pana/ } \\
\text { Pani waż- } \\
\text { ne w życiu }\end{array}$} & $\begin{array}{l}\text { być kimś lub } \\
\text { z kimś powszech- } \\
\text { nie znanym i po- } \\
\text { dziwianym }\end{array}$ & 154 & 4,26 & 140 & 4,70 & 0,075 & $p=0,385$ \\
\hline & $\begin{array}{l}\text { móc robić w życiu } \\
\text { tylko to, na co się } \\
\text { ma ochotę }\end{array}$ & 1291 & 35,70 & 1052 & 35,34 & 0,095 & $\mathrm{p}=0,785$ \\
\hline & $\begin{array}{l}\text { odnieść sukces } \\
\text { zawodowy }\end{array}$ & 855 & 23,64 & 715 & 24,02 & 0,125 & $p=0,724$ \\
\hline & $\begin{array}{l}\text { odnieść sukces } \\
\text { finansowy }\end{array}$ & 519 & 14,35 & 585 & 19,65 & 32,871 & $\mathrm{p}<0,01$ \\
\hline & $\begin{array}{l}\text { mieć zawsze przy- } \\
\text { jaciół }\end{array}$ & 2181 & 60,32 & 1428 & 47,97 & 100,767 & $\mathrm{p}<0,01$ \\
\hline & $\begin{array}{l}\text { mieć kochającą } \\
\text { rodzinę }\end{array}$ & 2834 & 78,37 & 2206 & 74,10 & 16,552 & $\mathrm{p}<0,01$ \\
\hline & $\begin{array}{l}\text { pomagać potrze- } \\
\text { bującym }\end{array}$ & 1028 & 28,43 & 623 & 20,93 & 48,956 & $\mathrm{p}<0,01$ \\
\hline & $\begin{array}{l}\text { dobrze i atrakcyj- } \\
\text { nie wyglądać }\end{array}$ & 99 & 2,91 & 111 & 4,08 & 6,326 & $\mathrm{p}<0,01$ \\
\hline
\end{tabular}

Źródło: opracowanie własne. 


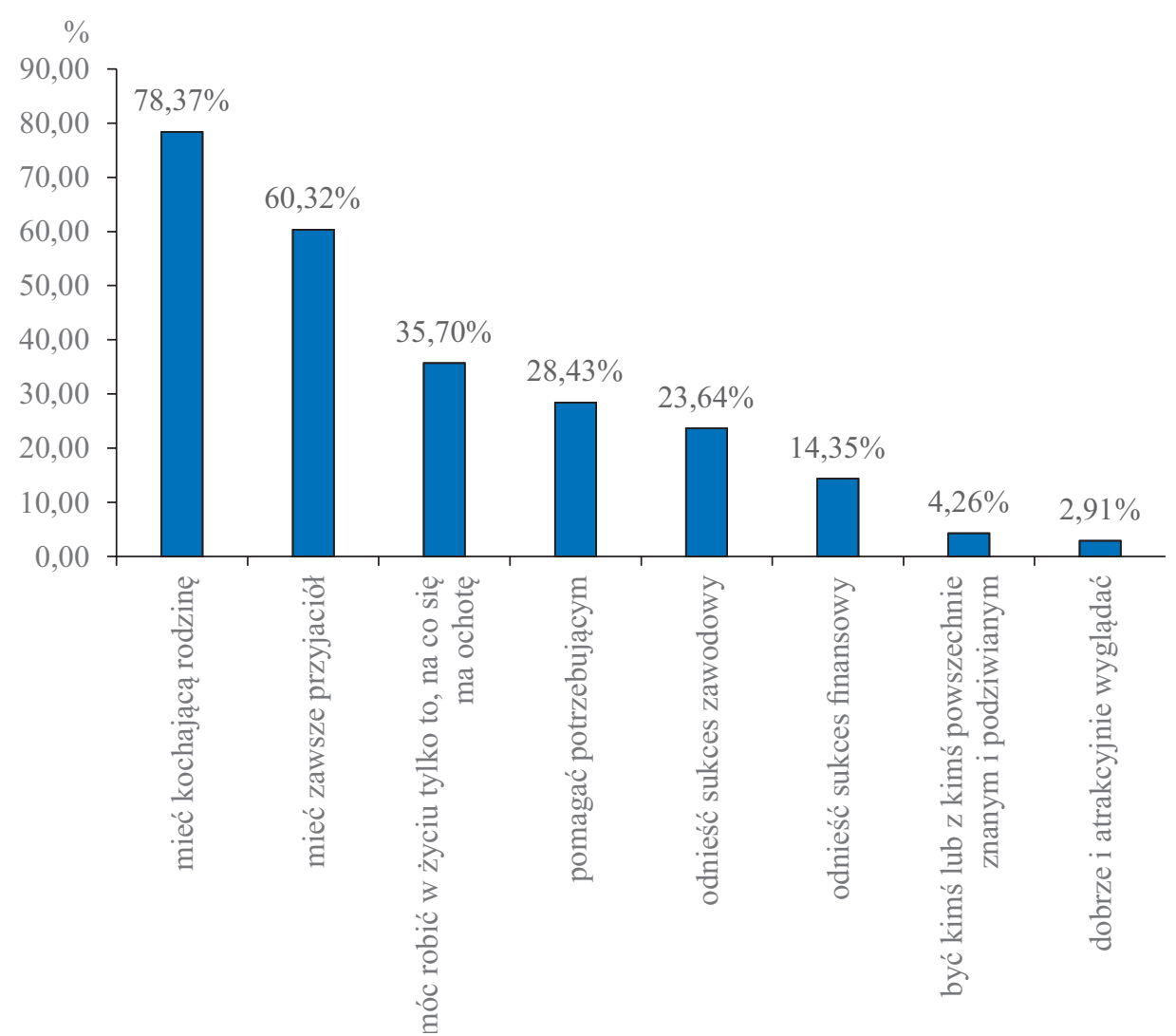

Wykres 6. Cele życiowe bibliotekarzy, którzy deklaruja, że „większości ludzi można ufać"

Źródło: opracowanie własne.

Kolejną ciekawą zależnością ujawnioną w badaniach jest: zaufanie do innych ludzi a aktywność społeczna bibliotekarzy. Istotnie statystycznie bibliotekarze, którzy deklarują, że „można ufać większości ludzi”, częściej (83,74\%) deklarują że kiedykolwiek zdarzyło im się dobrowolnie i nieodpłatnie pracować na rzecz swojego środowiska, Kościoła, osiedla, wsi, miasta albo też pracować społecznie na rzecz potrzebujących. Zatem zwiększone zaufanie przejawia się $\mathrm{w}$ większej aktywizacji społecznej. Ta sama grupa częściej deklaruje również, że zdarzyło jej się w ciągu ostatnich pięciu lat pracować w wolontariacie (51,26\%) (zob. tab. 2).

Co ciekawe, statystycznie bibliotekarze, którzy deklarowali, że „można ufać większości ludzi", istotnie uważaja, że ważne jest dla nich, by mieć kochającą rodzinę $(78,37 \%)$ oraz mieć zawsze przyjaciół $(60,32 \%)$. Najmniej ważne dla tej grupy respondentów były: atrakcyjny wygląd $(2,91 \%)$, 
Tabela 4. Statystyki poziomu indywidualnego kapitału społecznego według deklaracji zaufania do większości ludzi

\begin{tabular}{|l|c|c|c|c|}
\hline \multicolumn{4}{|c|}{ Poziom indywidualnego kapitału społecznego } \\
\cline { 1 - 4 } $\begin{array}{c}\text { Większości ludzi } \\
\text { można ufać }\end{array}$ & Średnia & $\mathrm{n}$ & $\begin{array}{c}\text { Odchylenie } \\
\text { standardo- } \\
\text { we }\end{array}$ & Test U Manna-Whitneya \\
\hline Tak & 68,33 & 3616 & 10,03 & \multirow{2}{*}{$\mathrm{Z}=-4,733 ; \mathrm{p}=0,005$} \\
\hline Nie & 64,81 & 2977 & 12,23 & \\
\hline
\end{tabular}

Źródło: opracowanie własne.

Tabela 5. Statystyki liczby znajomych według deklaracji zaufania do większości ludzi

\begin{tabular}{|l|c|c|c|c|}
\hline \multicolumn{5}{|c|}{ Liczba znajomych } \\
\cline { 1 - 4 } $\begin{array}{c}\text { Większości ludzi } \\
\text { można ufać }\end{array}$ & Średnia & $\mathrm{n}$ & $\begin{array}{c}\text { Odchylenie } \\
\text { standardo- } \\
\text { we }\end{array}$ & Test U Manna-Whitneya \\
\hline Tak & 28,33 & 3616 & 31,33 & \multirow{2}{*}{$\mathrm{Z}=-3,424 ; \mathrm{p}<0,01$} \\
\hline Nie & 24,33 & 2977 & 30,15 & \\
\hline
\end{tabular}

Źródło: opracowanie własne.

kontakt z powszechnie znanymi i podziwianymi osobami $(4,26 \%)$ oraz sukces finansowy (14,35\%) (zob. tab. 3, wykres 6). Jak zatem widać, wysoki poziom zaufania do innych ludzi koreluje z postawami społecznymi oraz celami i aspiracjami osobistymi.

W badaniach potwierdzono również wpływ zaufania do innych ludzi na poziom indywidualnego kapitału społecznego bibliotekarzy. Jak można było przypuszczać, istotnie statystycznie $(Z=-4,733$; $p<0,01)$ wyższy poziom indywidualnego kapitału społecznego obserwujemy u osób, które zadeklarowały, że „większości ludzi można ufać” (68,33 IKS), niż u tych, które deklarują przeciwnie (64,81 IKS) (tab. 4). Osoby deklarujące zaufanie w stosunku do innych posiadają również większą sieć społeczną. Istotnie statystycznie $(Z=-3,424 ; p<0,01)$ średnia liczba znajomych tych osób jest większa $(28,33)$ niż w wypadku tych, które deklarowały brak zaufania $(24,33)$ (tab. 5).

W tabeli 6 i na wykresie 7 zamieszczono z kolei statystyki dotyczące aktywności charytatywnej oraz obywatelskiej bibliotekarzy, z uwzględnieniem ich deklarowanego zaufania $\mathrm{w}$ stosunku do innych ludzi. Zarówno aktywność charytatywna, jak i aktywność obywatelska traktowane są w badaniach światowych jako przejaw kapitału społecznego. Zatem 


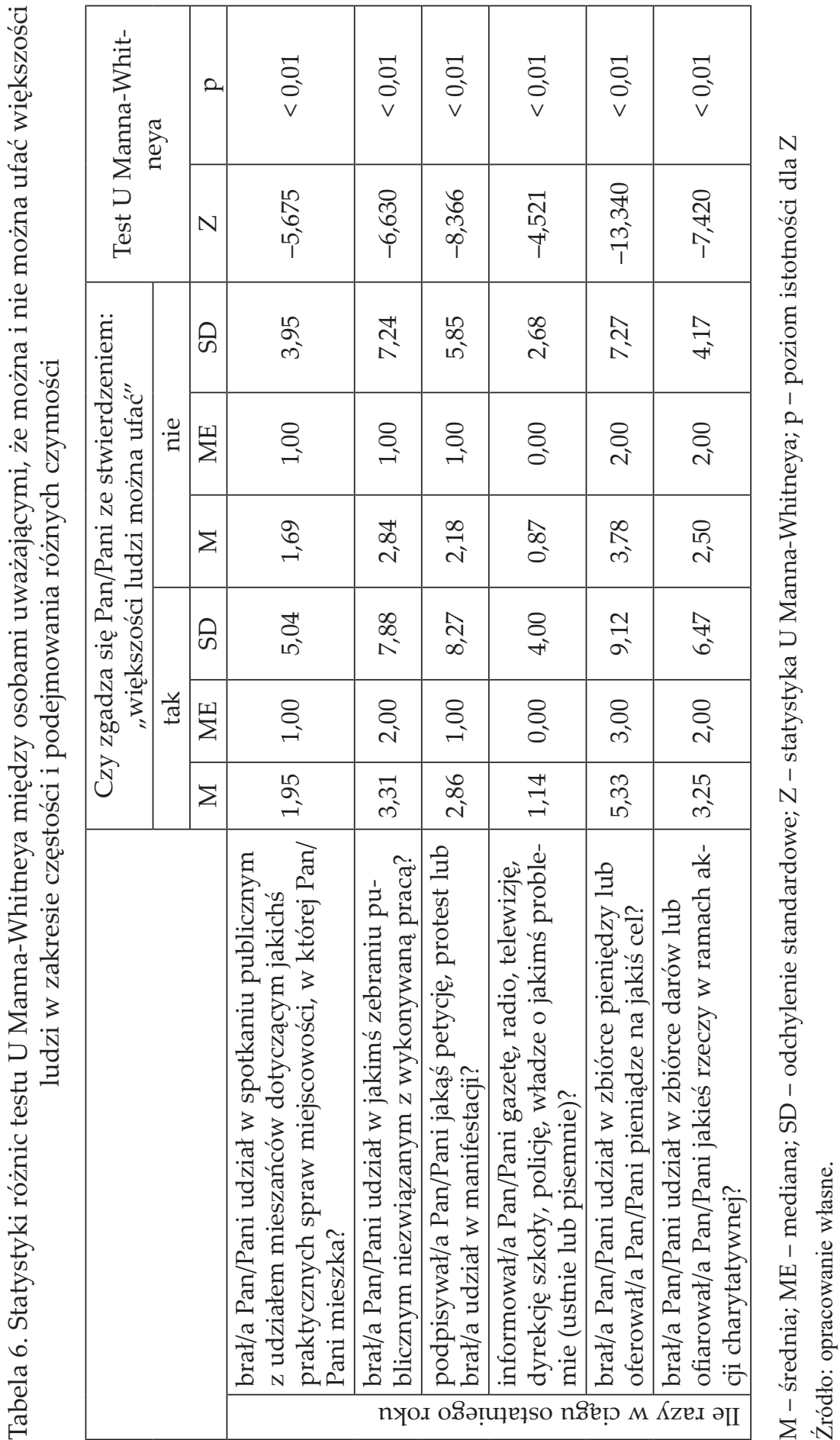




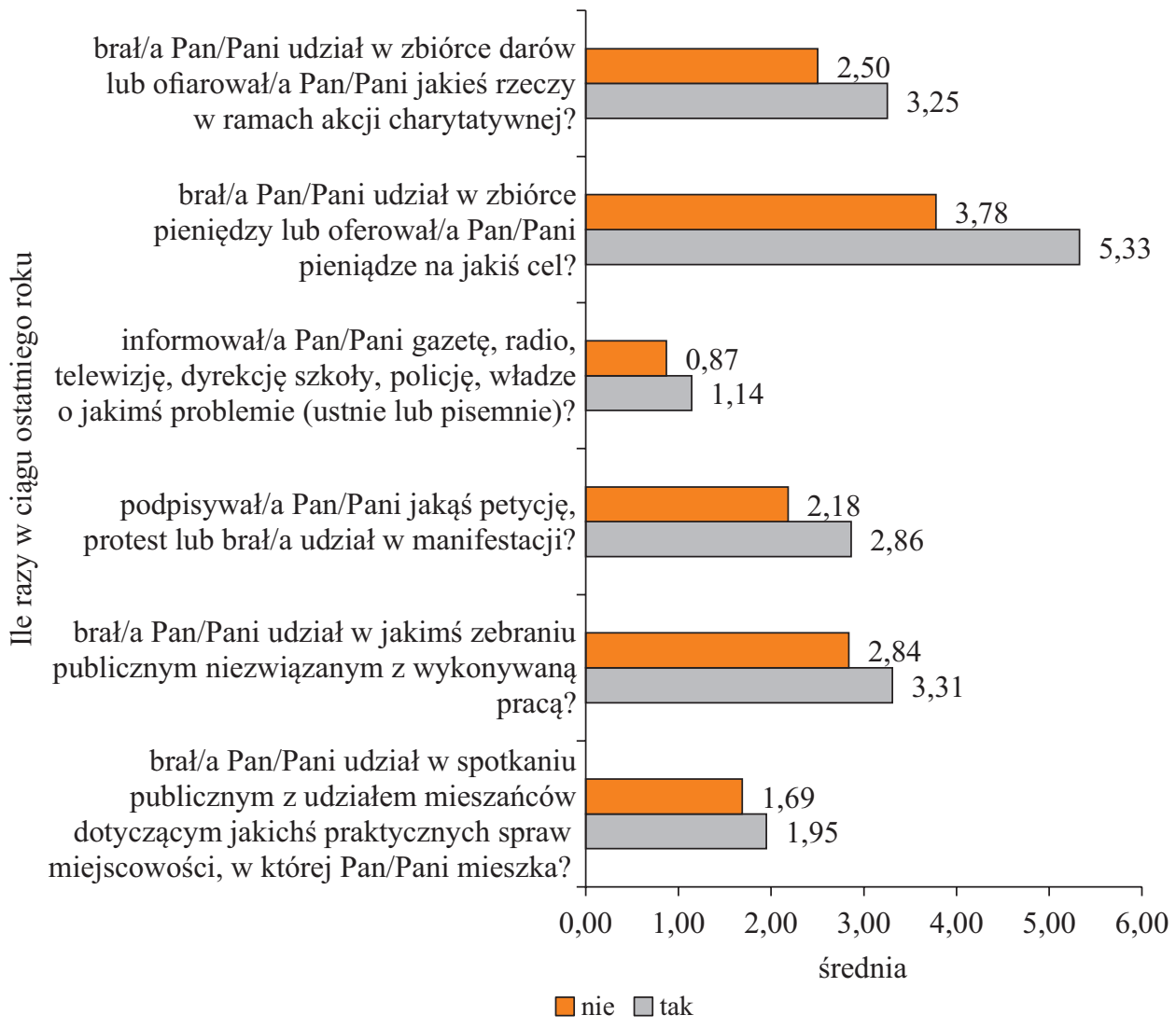

Wykres 7. Wykres wartości średnich częstości wykonywanych czynności w ciągu ostatniego roku w zależności od odpowiedzi na pytanie, czy można ufać większości ludzi

Źródło: opracowanie własne.

teoretycznie osoby o wysokim poziomie zaufania do innych i wysokim kapitale społecznym powinny również częściej angażować się w różnego rodzaju akcje wolontariackie, charytatywne, pomoc innym oraz aktywizować się w sferze obywatelskiej. Jak pokazały badania, zależność ta występuje również w grupie zawodowej bibliotekarzy. Każdy rodzaj aktywności społecznej, o który zapytani byli respondenci, jest średnio wyższy w grupie deklarującej zaufanie do innych ludzi, tj. bibliotekarze ufający innym częściej w ciągu roku podejmują działania społeczne i obywatelskie.

Jak zatem wynika z tabeli 6 i wykresu 7, we wszystkich wymienionych czynnościach pracownicy bibliotek deklarujący, że „można ufać większości ludzi", mają wyższe wyniki średnie. 


\section{Podsumowanie}

Zaufanie stanowi w działalności bibliotek istotny czynnik wpływający na relacje z obsługiwaną społecznością. Ważny jest poziom zaufania zarówno użytkowników do biblioteki, jak i bibliotekarzy w stosunku do ludzi ogółem, lokalnej społeczności, przełożonych, podwładnych oraz wszystkich współpracowników. Wysoki poziom zaufania generuje wiele korzyści: ogranicza formalizm, stosowanie sankcji, nakazów i kar, wprowadza korzystny klimat organizacyjny, zwiększa zaangażowanie i poczucie odpowiedzialności, ułatwia współdziałanie oraz sprzyja generowaniu nowych pomysłów i realizacji projektów. Brak zaufania powoduje, że część uwagi musi zostać nakierowana na kontrolę, która wskaże, czy partnerzy i użytkownicy wywiązują się ze swoich zobowiązań. Dla niektórych jednostek jest to czynnik zniechęcający, a grupy społeczne, które są słabo zaktywizowane kulturalnie i czytelniczo, mogą chcieć z biblioteką współpracować tylko w ograniczonym zakresie lub w ogóle zrezygnować z aktywności. W tym kontekście istotne wydaje się podjęcie badań wskazujących, które czynniki, zachowania i postawy mogą sprzyjać budowaniu zaufania w środowisku bibliotek. Jest to zadanie trudne i wielopłaszczyznowe, każda bowiem biblioteka funkcjonuje w innym otoczeniu, realizuje różne funkcje i zadania, jednak wymaga analizy - zwłaszcza w wypadku instytucji bibliotecznych, które chciałyby przyjąć strategię silnej integracji społecznej ze społecznością lokalną bądź obsługiwaną grupą odbiorców (specjalistów, fachowców, uczniów itd.).

Jak pokazały przeprowadzone przeze mnie badania, aż 95,2\% bibliotekarzy uważa, że biblioteka jest instytucją której można ufać, jednak już tylko 54,8\% zgodziło się ze stwierdzeniem, że „większości ludzi można ufać" (wykres 8). Przewrotnie można więc skomentować ten wynik: respondenci uważają że należy im ufać, lecz innym ludziom nie ufają już tak bardzo. Aby jednak zachować obiektywizm, trzeba podkreślić, że na tle innych środowisk jest to wynik bardzo dobry, przypomnijmy - średnia dla krajów OECD w indeksie zaufania w 1995 roku wynosiła $43 \%$, natomiast w badaniach poziomu zaufania w krajach Unii Europejskiej z 2008 roku najwyższy poziom osiągnęła Finlandia, nie uzyskując nawet $45 \%{ }^{23}$.

Przeprowadzona analiza pokazała, że pracownicy bibliotek dysponują potencjałem, który może zostać wykorzystany w celu poszerzania działalności bibliotek o realizację funkcji społecznych. Wyższy poziom zaufania

${ }^{23}$ Kapitat społeczny..., s. 212; Raport o Kapitale Intelektualnym... 


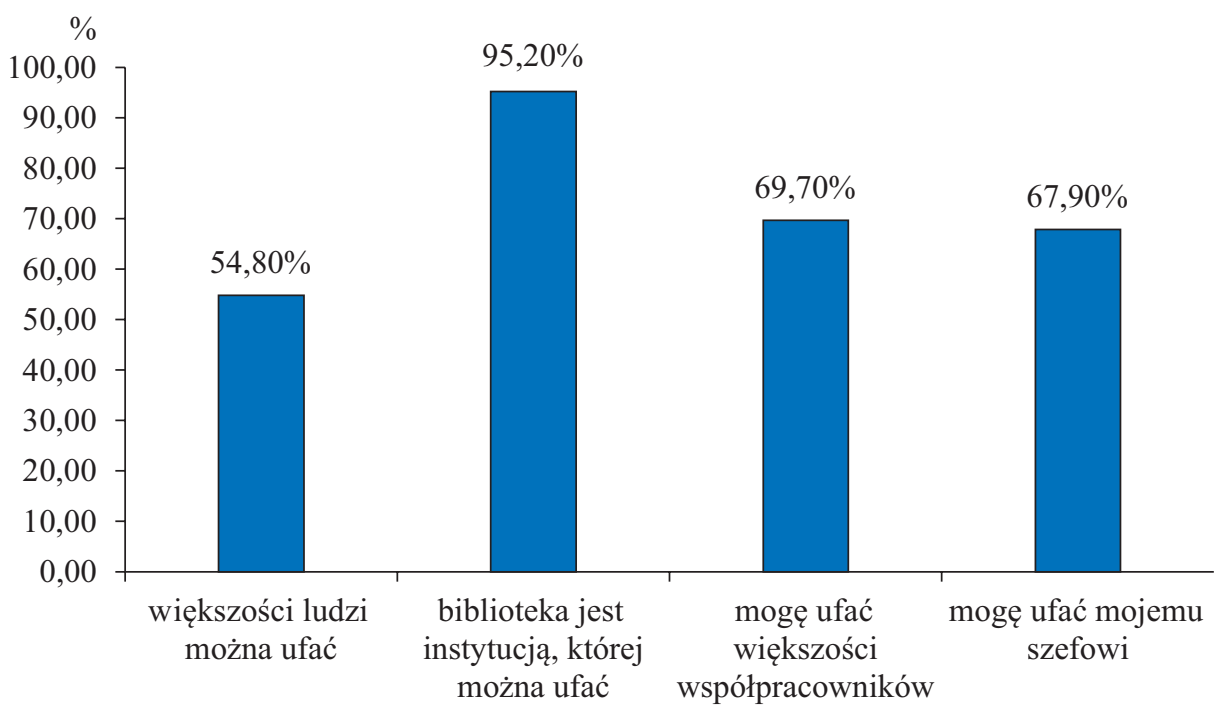

Wykres 8. Statystyki procentowe potwierdzające zaufanie do innych Źródło: opracowanie własne.

wśród bibliotekarzy niż obserwowany u reszty społeczeństwa skłania do wniosku, że biblioteki, po zapewnieniu im odpowiednich warunków materialnych i lokalowych, mogą angażować się w działania mające na celu integrację lokalnych społeczności oraz pobudzanie ich aktywności.

\section{Bibliografia}

American Library Association, Guidelines for outreach to immigrant populations, https://tinyurl.com/3tf6233a [dostęp: 12.12.2019].

Bazuń D., Kwiatkowski M., Lubuskie sieci inkluzji: tożsamość regionalna, kapitał społeczny, aktywna integracja, Warszawa: Dom Wydawniczy Elipsa 2015.

Cox E., A safe place to go. Libraries and social capital, https://www.sl.nsw.gov.au/ sites/default/files/safe_place.pdf [dostęp: 10.09.2020].

Działek J., Murzyn-Kupisz M., Rola bibliotek $w$ budowaniu $i$ wzmacnianiu zasobów kapitału społecznego w województwie małopolskim, "Zarządzanie Biblioteką" 2014, nr 1, s. 9-32.

Feliksiak M. (oprac.), Oceny działalności instytucji publicznych, 2018, nr 40, https:// www.cbos.pl/SPISKOM.POL/2018/K_040_18.PDF [dostęp: 10.11.2018].

Growiec K., Kapitał społeczny. Geneza i społeczne konsekwencje, Warszawa: Academica 2011.

Johnoson C.A., How do public libraries create social capital? An analysis of interactions between library staff and patrons, "Library and Information Science Research" 2012, nr 34, s. 52-62. 
Johnson C.A., Social capital and the search for information: examining the role of social capital in information seeking behavior in Mongolia, "Journal of the American Society for Information Science and Technology" 2007, nr 58, s. 883-894.

Kapitat społeczny: interpretacje, impresje, operacjonalizacja, red. M. Klimowicz, W. Bokajło, Warszawa: CeDeWu 2010.

Kisilowska M., Czy lubicie się Państwo zakładać? O zaufaniu w bibliotece, w: Biblioteka jako trzecie miejsce. Międzynarodowa Konferencja Biblioteki Uniwersytetu Łódzkiego, red. M. Wrocławska, J. Jerzyk-Wojtecka, Łódź: Wydawnictwo Uniwersytetu Łódzkiego 2011, s. 7-17.

Paul M., Wptyw społeczny bibliotek publicznych. Na przykładach inicjatywy bibliotecznej „Wykietkuj na rynku pracy” oraz korzystania z mazowieckich bibliotek publicznych, Warszawa: Uniwersytet Warszawski 2018, praca doktorska.

Putnam R., Samotna gra w kręgle: upadek i odrodzenie wspólnot lokalnych w Stanach Zjednoczonych, Warszawa: Wydawnictwa Akademickie i Profesjonalne 2008.

Putnam R.D., Leonardi R., Nanetti R.Y., Making democracy work: civic traditions in modern Italy, Princeton: Princeton University Press 1993.

Raport o Kapitale Intelektualnym Polski, Warszawa 2008, https://zds.kprm.gov.pl/ przegladaj-raport-o-kapitale-intelektualnym [dostęp: 27.10.2018].

Słownik języka polskiego, https://sjp.pwn.pl [dostęp: 10.06.2020].

Szałkowski A., Składniki kapitału społecznego, "Zeszyty Naukowe Uniwersytetu Ekonomicznego w Krakowie" 2007, nr 755, s. 7-20.

Sztompka P., Zaufanie. Fundament społeczeństwa, Kraków: Wydawnictwo Znak 2007.

Vårheim A., Gracious space: library programming strategies towards immigrants as tools in the creation of social capital, "Library \& Information Science Research" 2011, nr 1, s. 12-18.

Vårheim A., Public libraries: places creating social capital?, „Library Hi Tech” 2009, nr 3, s. 372-381.

Vårheim A., Steinmo S., Ide E., Do libraries matter? Public libraries and the creation of social capital, "Journal of Documentation” 2008, nr 6, s. 877-892.

Wojciechowska M., Kształtowanie kapitału społecznego - ujęcie z perspektywy bibliotekoznawczej, Warszawa: Difin 2019.

Wojciechowska M., Indywidualny kapitał społeczny i aktywność społeczna kadry kierowniczej bibliotek. Przegląd wyników badań z dwudziestu krajów świata, "Przegląd Biblioteczny" 2020, z. 4, s. 445-460.

Wojciechowska M., Kamińska J., Żołędowska-Król B., Jaskowska B., Leksykon zarzadzania i marketingu w bibliotekoznawstwie, Warszawa: Wydawnictwo Naukowe i Edukacyjne Stowarzyszenia Bibliotekarzy Polskich 2019. 


\title{
MAJA WOJCIECHOWSKA
}

\section{The role of trust in building and enhancing social capital in the professional environment of libra- rians. Study results}

\begin{abstract}
This article discusses the issue of the "trust" relationship that is considered to be a prerequisite and a necessary condition for building social capital. Social capital and trust play an important role in operation of a great number of institutions and societies, including libraries. Both support and enhance relationships with the local environment, improve co-operation with partners and co-workers, diminish fear and reduce conflicts, and are also stimulants in development. To properly diagnose this particular phenomenon within the library environment, relevant studies have been carried out in 20 countries all over the world. The analysis presented in the article includes both an attempt at establishing the level of trust within the professional group of librarians and the degree of its correlation with other factors (independent variables, such as the age, type of library, library position, etc., and dependent variables). It has been established that librarians show high level of trust towards other people, while the respondents who declared their trust towards other people are also characterised by higher level of individual social capital, enjoy participation in larger social networks and are more involved in charity and public-spirited activities. The latter group includes people who are also family-oriented and enjoy friendship contacts. All the mentioned social attitudes seem to be of significant value in particular library positions.
\end{abstract}

Key words: trust, social capital, social networks, libraries.

Tekst wpłynął do Redakcji 10 lipca 2020 roku. 
